\title{
STUDY THE IMPACT OF CONVECTIVE DRYING ON THE QUALITY OF TWO TYPES OF ONION
}

\author{
Mona M. Hassan* and Taghreed H. Ahmed**
}

\begin{abstract}
In this study a convective dryer was used to dry two types of onion (red and white) under three different thickness $(0.5,1$ and $2 \mathrm{~cm})$ and two different levels of air temperatures (65 and $80{ }^{\circ} \mathrm{C}$ ) to esteem drying characteristics, quality evaluation and the effective moisture diffusivity. At the end of the experiments, the samples were reached $8 \pm 1 \%$, w.b. moisture content. The effect of air drying temperature was respectable on the drying time. The Page and Modified Page (I) models were the best compatible models for all treatments. For dried samples quality assessment, the total color change $(\delta E)$ was better in the dried slices at lower temperature in both types for all slices thickness. The rehydration ratio extended from 2.03 to 2.68 at different parameters. Generally, the rehydration ratio was preferable at low temperature with regard to the two types of dried onions. From the results of quality assessment, convective drying has no defect to the dried samples, so that it is one of the best ways to dry onions. Effective moisture diffusivity of white onion extended from $1.50 \times 10^{-7}$ to $4.90 \times 10^{-7} \mathrm{~m}^{2} . \mathrm{s}^{-1}$, however red onion, extended from $6.25 \times 10^{-7}$ to $6.50 \times 10^{-6} \mathrm{~m}^{2} . \mathrm{s}^{-1}$. The moisture diffusivity increased as drying air temperature increased for both types of onion.
\end{abstract}

\section{INTRODUCTION}

$\mathrm{O}$ nions are one of the most popular vegetables in the world. This led to increase the indigence for dried onions in recent years. Drying is ordinarily operated to reduce bulk treating so as to preserve vegetables with a view to facilitate transportation and to allow their use during the off season. Dried onion is the most important product in the world trade as peeled, crushed, severed and grinded, (Arslan and Özcen, 2008). Mathematical modeling of drying experimental is used as an indicator to select the good method for drying a product.

"Associate Prof. of Agric. Eng., Fac. of Agric., Zagazig Univ., Egypt.

**Lecturer of Agric. Eng., Fac. of Agric., Zagazig Univ. 
The advanced models are used to styling new drying ways, determine the best drying conditions and to foretell simultaneous heat and mass transfer through the drying process. Many researchers have sophisticated models to describe the drying conduct of agrarian products (Khazai and Daneshmandi, 2007).(El Mesery and Mwithiga,2012) investigated The drying behavior of onion slices by using two types of dryers, vertical and horizontal convective hot air draying, drying air temperatures were 50, 60 or $70^{\circ} \mathrm{C}$, while air velocity was set at $0.5,1.0$ or $2.0 \mathrm{~m} . \mathrm{s}^{-1}$., they found the Page model was the best in describing the drying behavior of onion slices when compared to the other models, in addition the drying time in the case of the horizontal convective hot air dryer in comparison with vertical convective hot air dryer was considerably less while onion slices dried at higher temperatures generally had higher rehydration ratios. In hot air dryer, the final moisture contents were 10.89 and $10.87 \%$ at $50^{\circ} \mathrm{C}, 9.28$ and $9.58 \%$ at $60^{\circ} \mathrm{C}, 6.39$ and 7.69 at $70 \%$ for the white and red onions respectively. However, the drying rate increased with the increasing of the temperature of air, (Olulusi,2014).

So, the specific objectives of this study were to:

- Determine the impact of air temperature on drying time and drying rate.

- Evaluate the product quality in terms of color, moisture diffusivity and rehydration ratio.

- Study several drying models to express the drying kinetics of onion slices.

\section{MATERIALS AND METHODS}

The study was carried out through the season of 2018 at Faculty of Agriculture, Zagazig University to determine the appropriate conditions for drying white and red onions in hot air dryer.

Two types of onion(Allium cepa $\mathbf{L}$.):white and red onion. The onions were husked manually then sliced with a sharp knife into circular slices. Experiments conducted by a convective dryer, Philips type, model HD 9920, frequency: $50 / 60 \mathrm{~Hz}$, power: $1425 \mathrm{~W}$, voltage: $110 \mathrm{~V}$, drying chamber dimensions $\mathrm{H} 31.5 \times \mathrm{W} 28.7 \times \mathrm{D} 38.4 \mathrm{~cm}$, alterable temperature control and made in China. 
As shown in figure 1 there are an electricity heating unit was used as heat source for drying air. The heating unit was housed inside an isolated housing located above the drying chamber. Air drying is drawn from the outside by a fan and passes vertically through the heating unit in order to reach the required level of drying air temperature. This fan removed the moisture from drying chamber by passing it through outlet openings on the back of the dryer wall to the outer atmosphere.

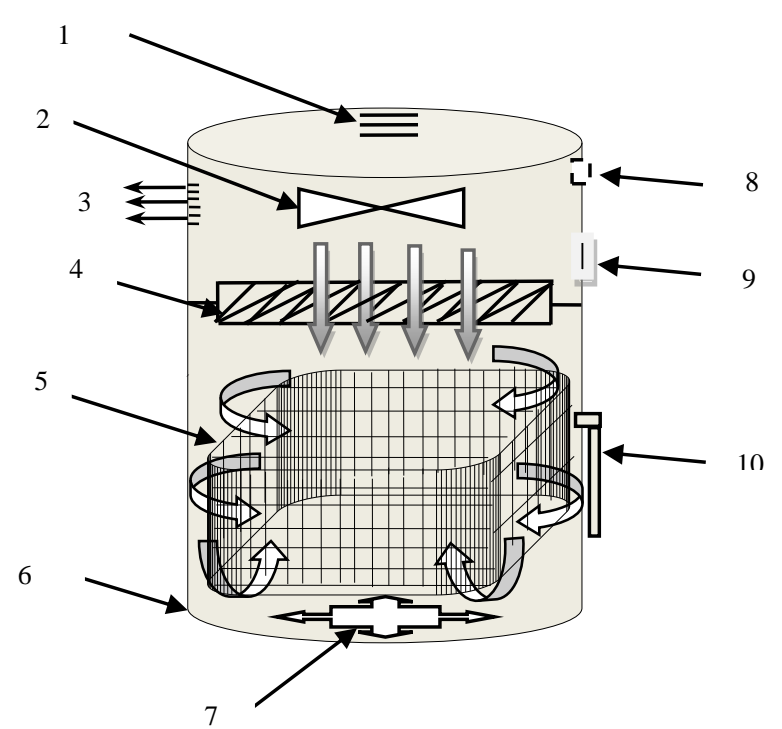

1- Air inlet

2- Fan

3- Air outlet

4- Heater

5- Basket
6- Drying chamber

7- Cavities

8- Temperature control

9- Timer

10- Basket handle

Fig. 1 A schematic diagram of the convective dryer.

\section{- Experimental procedure:}

The onion slices were regularly spread on the dryer basket and put in the pan container inside the drying chamber. The weight of samples at the beginning of the experiment $250 \mathrm{~g}$. The weight was measured every 10 minutes. The experiments were conducted till the moisture content reached $(8 \pm 1 \%$, w.b.).

The performance of the drying process was measured under the following parameters:

- Two different types of onion: white and red onions. 
- Three different thicknesses $(0.5,1$ and $2 \mathrm{~cm})$.

- Two different air temperatures $\left(65\right.$ and $\left.80^{\circ} \mathrm{C}\right)$.

\section{- Measurements:}

Evaluate the performance of the drying operation was based on these points:

- Moisture content: was set by drying the samples into a vacuum furnace at $105^{\circ} \mathrm{C}$ till reaching a fixed weight (AOAC, 2000). Moisture content of onion types were 86.00 and87.50\% w.b. for white and red onions respectively. The moisture losses of samples were registered through the drying process by a digital balance (Ming Heng K1) with a rigor of \pm 0.01 g. For measuring the bloc of the sample during experimentation, the griddle with sample was bring out from the drying chamber, weighed by the digital top balance and was returned back to the chamber.

- Drying rate: was calculated as following:

$$
D r=\frac{\left(M_{t+d t}-M_{t}\right)}{(d t)}
$$

Where: $\mathrm{M}_{\mathrm{t}}$ : Moisture content (g water/g dry matter) at time (t); $\mathrm{M}_{\mathrm{t}+\mathrm{dt}}$ : Moisture content ( $\mathrm{g}$ water/g dry matter) at time $(\mathrm{t}+\mathrm{dt})$.

-Quality appreciation: to appreciation the quality of dehydrated samples has evaluated on two parameters such as, color and rehydration ratio.

-Color assessment: the color of the dried onion slices was specified using the Hunter Color Lab (Hunter lab Color flex, Reston, VA, USA).The instrument was standardized by standard black and white plates, and setting the dried samples over the glass plate. Color values were used to calculate the total color change $(\delta E)$.

$$
\delta E=\sqrt{\left(L_{\mathrm{o}}-L\right)^{2}+\left(a_{\mathrm{o}}-a\right)^{2}+\left(b_{\mathrm{o}}-b\right)^{2}}
$$

Total color change was calculated by the following equation, where subscript " 0 " pointing to the color reading of the original plant. A larger $\delta \mathrm{E}$ betokens greater color change from the original plant (Mohammadi et al., 2008). 
The browning indicator (BI), was calculated by the following equations. (Maskan, 2001):

$$
B I=\frac{100(x-0.31)}{0.17} \quad, \quad x=\frac{a+1.75 L}{5.645 L+a-3.012 b} \quad \text { Where: }
$$

$\mathrm{a}=$

redness/greenness, $\mathrm{a}_{0}$ is the original value of $\mathrm{a} ; \mathrm{L}=$ white sensor brightness/darkness, $\mathrm{L}_{0}$ is the original value of $\mathrm{L}$ and $\mathrm{b}$ $=$ yellowness/blueness, $\mathrm{b}_{0}$ is the original value of $\mathrm{b}$. The values of $\delta E, \mathrm{BI}$ and $x$ elucidate

\section{- Rehydration ratio and coefficient of rehydration:}

The rehydration ratio was estimated by placing $10 \mathrm{~g}$ of samples with 1000 $\mathrm{ml}$ of boiling water about 5 minutes (Maskan ,2001).

Rehydration ratio and coefficient of rehydration were evaluated by these equations:

$$
R r=\frac{W_{r}}{W_{d}} \quad C O R=\frac{W_{r}\left(100-M_{i}\right)}{W_{d}\left(100-M_{f}\right)}
$$

where: $W_{r}$ is the drained weight of the rehydrated sample, $\mathrm{g}, W_{d}$ is the weight of the dry sample, $\mathrm{g}, \mathrm{M}_{\mathrm{i}}$ is moisture content of samples before dehydration, \% (wb) and $\mathrm{M}_{\mathrm{f}}$ is moisture content of dehydrated samples, \% (wb);

\section{-Moisture ratio and mathematical modeling}

The moisture ratio (MR) was calculated using the equation:

$$
M R=\frac{M_{t}-M_{e}}{M_{o}-M_{e}}
$$

Where: $\mathrm{M}_{\mathrm{t}}$ : Moisture content at $\mathrm{t}, \mathrm{db} ; \mathrm{M}_{\mathrm{e}}$ : the equilibrium moisture content, $\mathrm{db} ; \mathrm{M}_{\mathrm{o}}$ : the initial moisture content, $\mathrm{db}$.

The value of $M_{e}$ is relatively small compared with $M_{t}$ or $M_{o}$. Therefore, the moisture ratio (MR) was simplified to $\left(\mathrm{M}_{\mathrm{t}} / \mathrm{M}_{\mathrm{o}}\right)$.

Five semi-empirical models were applied to fit the experimental moisture data because they are widely used in drying agriculture products and they are equalities that explain the characteristic of the drying method in a safe way, as listed in Table 1. 
Table (1): Mathematical models given by various authors for the drying curves

\begin{tabular}{|c|c|c|}
\hline Models & Equations & References \\
\hline Newton & $M R=\exp (-k t)$ & (Liu and Bakker, 1997). \\
\hline Page & $\mathrm{MR}=\exp \left(-k \mathrm{t}^{\mathrm{n}}\right)$ & $\begin{array}{l}\text { (Zheng and Letchfield, } \\
\text { 1991). }\end{array}$ \\
\hline Modified Page (I) & $\mathrm{MR}=\exp \left[-(\mathrm{kt})^{\mathrm{n}}\right]$ & $\begin{array}{l}\text { (Zheng and Letchfield, } \\
\text { 1991). }\end{array}$ \\
\hline $\begin{array}{l}\text { Modified Page } \\
\text { (II) }\end{array}$ & $M R=\exp \left[\left(-k\left(t / L^{2}\right)^{n}\right)\right]$ & $\begin{array}{l}\text { (Diamante and Munro, } \\
\text { 1991) }\end{array}$ \\
\hline $\begin{array}{l}\text { Henderson and } \\
\text { Pabis }\end{array}$ & $M R=a \exp (-k t)$ & (Chhninman, 1984). \\
\hline
\end{tabular}

-Statistical analysis:

The Microsoft office excels (2010) was used for analysis and interpretation the results. To evaluate the righteousness of the fit of the models some several statistical parameters were used like; coefficient of determination $\left(\mathrm{R}^{2}\right)$, reduced chi square $\left(\mathrm{X}^{2}\right)$, mean bias error (MBE) and root mean square error (RMSE).These parameters can be calculated as follows:

$$
\begin{gathered}
x^{2}=\frac{\sum_{i=1}^{n}\left(M R_{\mathrm{exp}, i}-M R_{p r e, i}\right)^{2}}{N-n} \\
M B E=\frac{1}{N} \sum_{i=1}^{N}\left(M R_{p r e, i}-M R_{\exp , i}\right) \\
R M S E=\left[\frac{1}{N} \sum_{i=1}^{n}\left(M R_{p r e, i}-M R_{\mathrm{exp}, i}\right)^{2}\right]^{\frac{1}{2}}
\end{gathered}
$$

Where: $\mathrm{MR}_{\text {exp,i }}$ is the experimental moisture ratio in any measurement; $\mathrm{MR}_{\text {pre, }}$ is the predicted moisture ratio for this measurement; $\mathrm{N}$ is number of observations and $n$ is number of constants.

\section{-Effective moisture diffusivity:}

The experimental drying data for the determination of diffusivity coefficients were interpreted by using Fick's second diffusion model, to describe the interior moisture transfer through drying operation. 


$$
\frac{\partial \mathrm{M}}{\partial \mathrm{t}}=\mathrm{D}_{\text {eff }} \nabla^{2} \mathrm{M}
$$

The settling of diffusion equation for slab geometry is settled by (Crank, 1975) and assumed uniform initial moisture distribution, small external resistance, constant diffusivity and small shrinkage:

$$
M R=\frac{8}{\pi^{2}} \sum_{n=0}^{\infty} \frac{1}{(2 n+1)^{2}} \exp \left(-\frac{(2 n+1)^{2} \pi^{2} D_{\text {eff }} t}{4 L^{2}}\right)
$$

Where: $\mathrm{D}_{\text {eff }}$ is the effective moisture diffusivity $\left(\mathrm{m}^{2} / \mathrm{s}\right), t$ is the time (s), $L$ is the half thickness of samples (m) and $n$ is a positive integer. For long drying times, a limiting of this equation is obtained and expressed in a logarithmic form (Madamb, 2003):

$$
\operatorname{lnMR}=\ln \frac{8}{\pi^{2}}-\frac{\pi^{2} \mathrm{D}_{\text {eff }} \mathrm{t}}{4 \mathrm{~L}^{2}}
$$

The effective diffusivity is calculated by putting data in terms of $\ln (\mathrm{MR})$ against time.

\section{RESULTS AND DISCUSSION}

\section{- Drying kinetics}

Figures 2 and 3 show the difference in moisture content versus drying time for red and white onion slices at 65 and $80^{\circ} \mathrm{C}$ with different slice thicknesses, $0.5,1$ and $2 \mathrm{~cm}$. It is obvious that by checking these curves, the drying onion at $65^{\circ} \mathrm{C}$ was much slower than at $80^{\circ} \mathrm{C}$ with all treatments. For example, in red onion, it took 50,70 and $90 \mathrm{~min}$ at $80^{\circ} \mathrm{C}$ at $0.5,1$ and $2 \mathrm{~cm}$ slice thicknesses respectively, however, at $65^{\circ} \mathrm{C}$, it took 110,130 and $220 \mathrm{~min}$, at $0.5,1$ and $2 \mathrm{~cm}$ slice thicknesses respectively.

Therefore, temperature of drying air has significant effect on the drying time. Identical results observed for white onion.

The drying rates of onion slices dried by various treatments are given in Figure 4 and 5. It is evident that, the whole drying for experimented plants occurs in the range of the falling rate period. At the first phase of drying, the drying rate increased, because of the high moisture content for all treatments. 

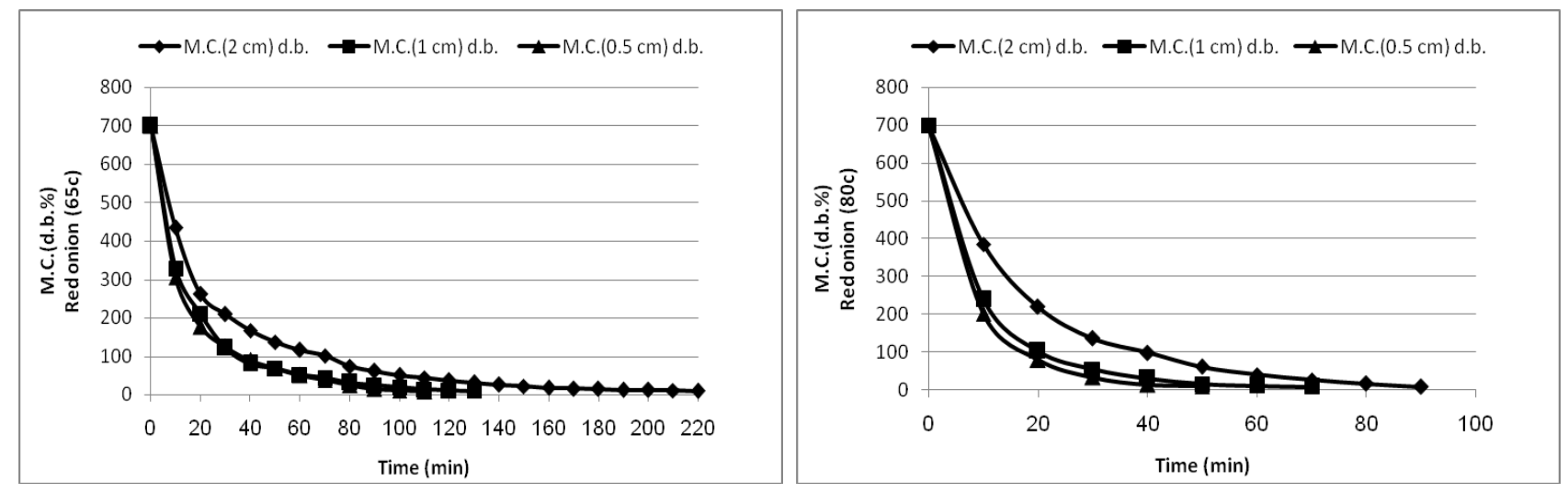

Fig.2. Moisture content versus drying time for red onion slices at different treatments.
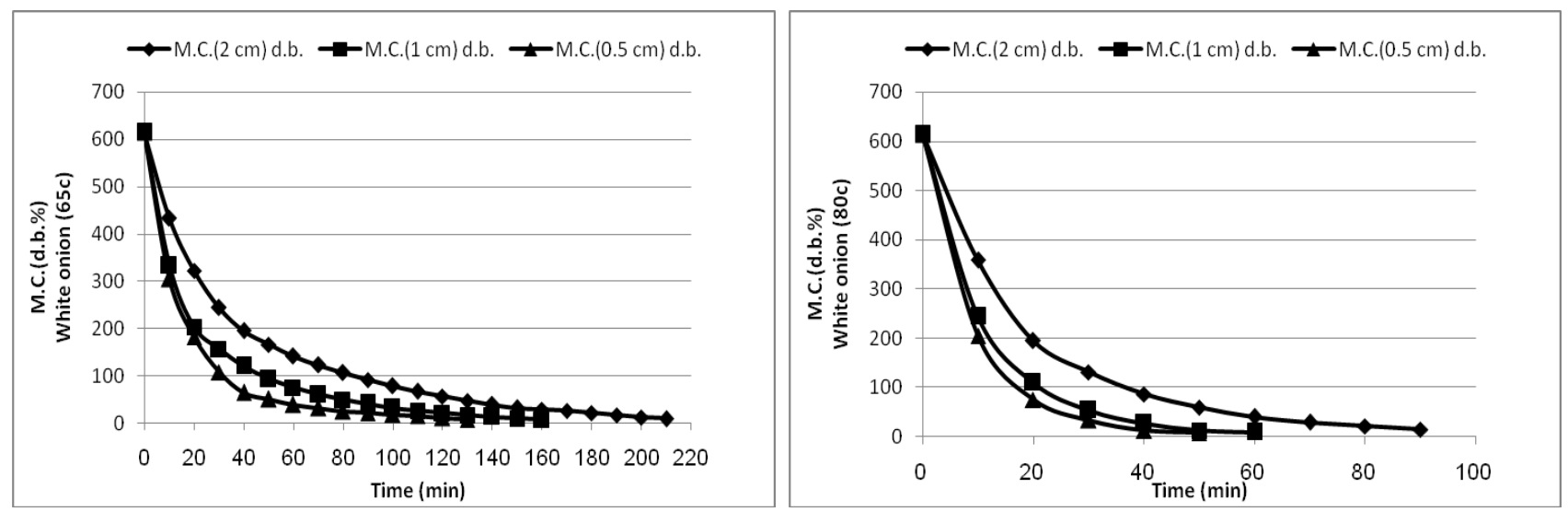

Fig.3. Moisture content versus drying time for white onion slices at different treatments. 

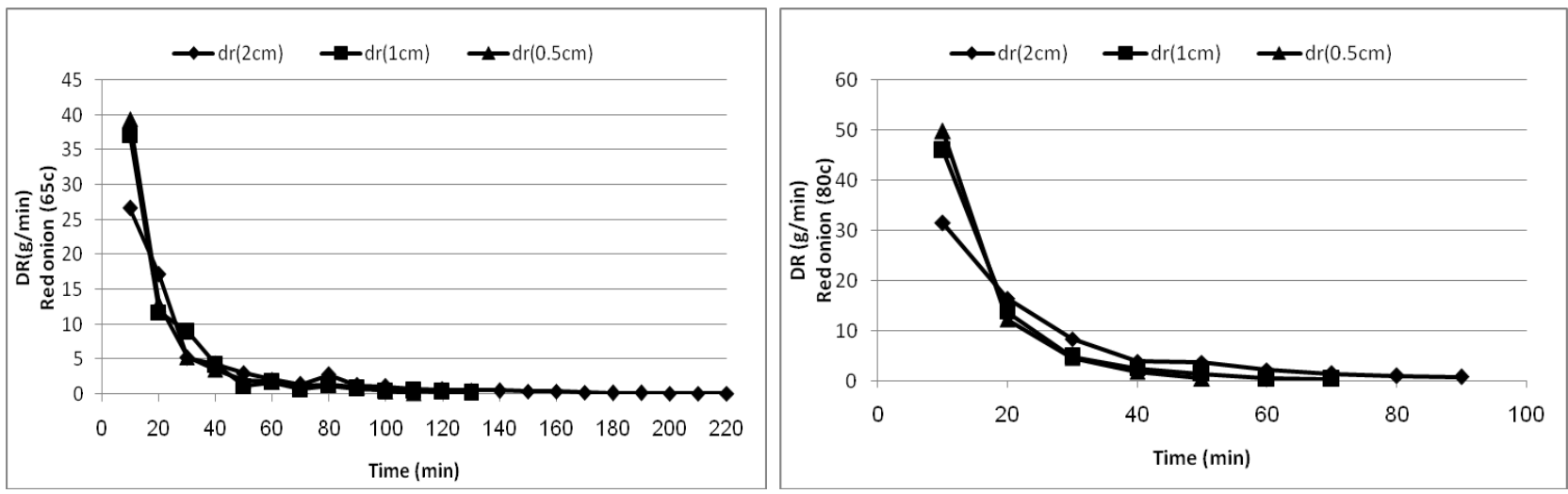

Fig.4. Drying rate of red onion slices at different temperatures.
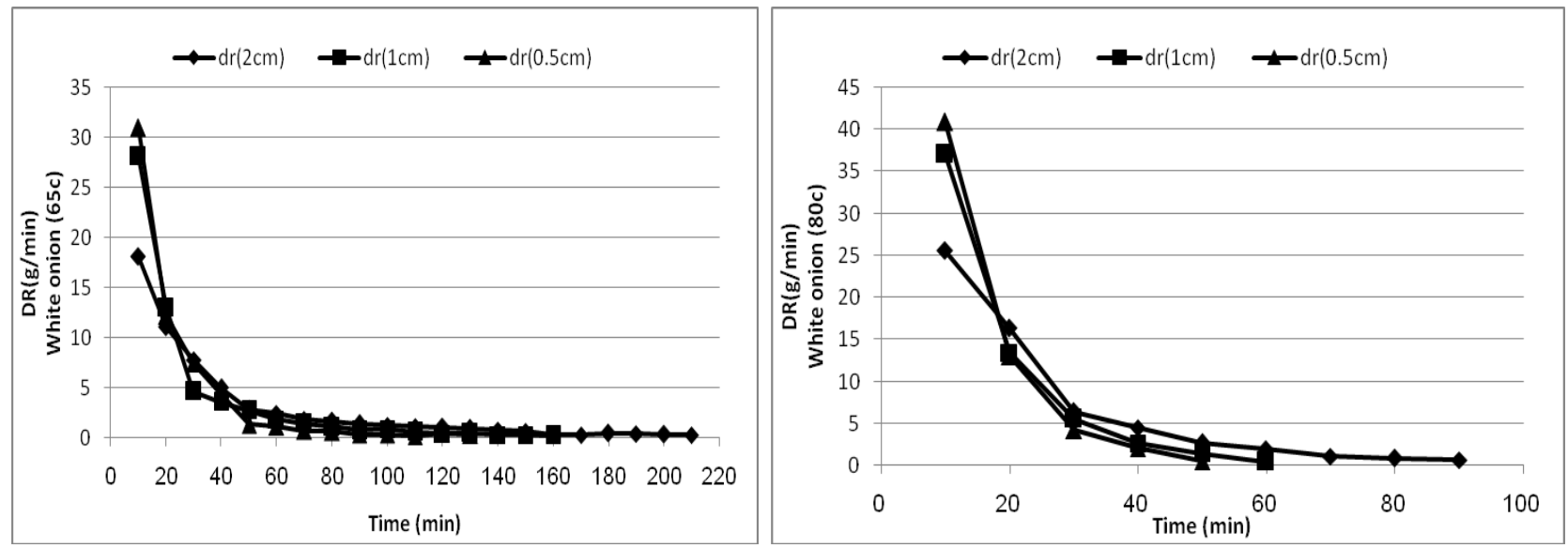

Fig.5. Drying rate of white onion slices at different temperatures. 


\section{- Mathematical Modeling of Drying Data}

The data of moisture content against time were transformed to moisture ratio against time to normalize the drying curves. The data at different curve fitting computations with the drying time were conducted on five drying models predestined by the previous workers. The results of statistical analyses pledge on these models are given in tables 2,3,4 and 5, respectively. The predestined of the models were based on $\mathrm{R}^{2}, \mathrm{X}^{2}$, MBA and RMSE. For red onion at 65 and $80{ }^{\circ} \mathrm{C}$, the Page and Modified Page (I) models were the best descriptive models for all slice thicknesses as shown in table 2 and 3. For example at thickness $2 \mathrm{~cm}$, it was determined that $\mathrm{R}^{2}=0.994, \mathrm{X}^{2}=0.039697, \mathrm{MBE}=-0.120834$ and $\mathrm{RMSE}=$ 0.189968 for the Page model for $65{ }^{\circ} \mathrm{C}$ dying temperature. the same results for white onion at 65 and $80{ }^{\circ} \mathrm{C}$, the Page and Modified Page (I) models were the best descriptive models for all slice thicknesses as shown in table 4 and 5. For example at thickness $2 \mathrm{~cm}$, it was determined that $\mathrm{R}^{2}$ $=0.993, X^{2}=0.053621, \mathrm{MBE}=-0.147524$ and $\mathrm{RMSE}=0.220259$ for the Page model for $65^{\circ} \mathrm{C}$ dying temperature.

\section{- Quality evaluation of dried onion slices:}

Table 6 clarifies the color changes of onion slices in terms of color differences. In the case of lightness it was found that the slices thickness did not as significantly affect the change of lightness as drying temperature. However, the $\mathrm{L}^{*}$ (lightness) increased at higher drying temperatures especially in both varieties for all slices thickness. Also, the results indicated that the total color change $(\delta \mathrm{E})$ was greater in the dried slices at lower temperature in both varieties for all slices thickness, because it took longer time to reach the required moisture content at lower temperature. The changes of redness of slices treated at $80{ }^{\circ} \mathrm{C}$ were did not statistically differ than those at $65{ }^{\circ} \mathrm{C}$ for white onion but for red onion were significantly differ. The yellowness (b value) did not show any significant influence with both different drying temperatures and different slice thicknesses for white onion but for red onion were significantly differing.

\section{-Browning indicator}

The effects of drying temperatures and slice thicknesses on the browning indicator of the two varieties are shown in Table 2. The results were not 
significantly different with different slice thicknesses and different drying temperatures. From the results of color changes and browning indicator it might be concluded that hot air drying did not cause any defect to onion slices. So it is a good way to dry onions and to maintain quality.

\section{-Rehydration Characteristics}

The quality of the dried onion slices was estimated after the rehydration of the dried onion slices. The rehydration of the dried onion slices is dependent on the range of the slice deterioration during the drying operation. The dried slices of onion were significantly differed from the fresh due the removal of large quantities of water. The rehydration ratio of dried onion slices is presented in table 6. The rehydration ratio and coefficient of rehydration were calculated to return to the base block of the dried onions. Higher rehydration ratio indicates better product. The rehydration ratio ranged from 2.03 to 2.68 at different parameters. The two varieties of the dried onions were have greater rehydration ratio at lower temperature $\left(65^{\circ} \mathrm{C}\right)$ compared with the sample dried at higher temperature $\left(80^{\circ} \mathrm{C}\right)$. At lower temperatures, plant cells are less vandalized, so that the material is capable of more absorption of water. It was noted that as the temperature decreased, the coefficients of rehydration increased. It can be observed that there is no difference in the rehydration ratio and coefficient of rehydration with different parameters.

\section{-The effective diffusivity}

The effective diffusivities were predestined from the experimental drying curves. To predestine diffusion coefficients $\left(D_{\text {eff. }}\right)$, the slope of $\ln (\mathrm{MR})$ versus time in Fig. 6 and 7 were used.

Effective moisture diffusivity of white onion ranged from $1.50 \times 10^{-7}$ to $4.90 \times 10^{-7} \mathrm{~m}^{2} . \mathrm{s}^{-1}$ and for red onion ranged from $6.25 \times 10^{-7}$ to $6.50 \times 10^{-6} \mathrm{~m}^{2} \cdot \mathrm{s}^{-}$ ${ }^{1}$. The moisture diffusivity increased as drying air temperature increased for both varieties of onion. Same results with different slice thicknesses proved that the moisture diffusivity increased as slice thicknesses increased for both varieties of onion. For white onion, the maximum $\mathrm{R}^{2}$ value was 0.992 at $80^{\circ} \mathrm{C}$ and $2 \mathrm{~cm}$ thickness but it was minimum 0.983 at $65^{\circ} \mathrm{C}$ and thickness of $1 \mathrm{~cm}$. However, for red onion, the maximum $\mathrm{R}^{2}$ value was 0.984 at $65^{\circ} \mathrm{C}$ and $0.5 \mathrm{~cm}$ thickness and it was minimum of 0.960 at $80^{\circ} \mathrm{C}$ and $2 \mathrm{~cm}$ thickness. 
Table (2): Statistical analyses of fitted mathematical models to thin layer drying data of red onion at $65 \mathrm{C}^{0}$.

\begin{tabular}{|c|c|c|c|c|c|c|c|c|c|}
\hline \multirow{2}{*}{ Model } & \multirow{2}{*}{ Thickness } & \multicolumn{4}{|c|}{ Constants } & \multirow{2}{*}{$\mathbf{R}^{2}$} & \multirow{2}{*}{$X^{2}$} & \multirow{2}{*}{ MBE } & \multirow{2}{*}{ RMSE } \\
\hline & & $\mathbf{k}$ & $\mathbf{n}$ & $\mathbf{a}$ & $\mathbf{b}$ & & & & \\
\hline \multirow{3}{*}{ Newton } & 2 & 0.018 & & & & 0.975 & 0.028270 & -0.111833 & 0.164270 \\
\hline & 1 & 0.031 & & & & 0.970 & 0.019232 & 0.0968494 & 0.133240 \\
\hline & 0.5 & 0.037 & & & & 0.984 & 0.015465 & 0.0816106 & 0.1185716 \\
\hline \multirow{3}{*}{ Page } & 2 & 24.73 & 1.456 & & & 0.994 & 0.039697 & -0.120834 & 0.189968 \\
\hline & 1 & 14.49 & 1.477 & & & 0.994 & 0.034333 & -0.111050 & 0.170444 \\
\hline & 0.5 & 13.62 & 1.44 & & & 0.991 & 0.035682 & -0.117964 & 0.1708632 \\
\hline \multirow{3}{*}{ Modified Page (I) } & 2 & 9.058 & 1.456 & & & 0.994 & 0.039697 & -0.120834 & 0.189968 \\
\hline & 1 & 6.113 & 1.477 & & & 0.994 & 0.034333 & -0.158922 & 0.298361 \\
\hline & 0.5 & 6.134 & 1.44 & & & 0.991 & 0.035682 & -0.117964 & 0.170863 \\
\hline \multirow{3}{*}{ Modified Page (II) } & 2 & 0.0619 & 1.456 & & & 0.994 & 0.850775 & 0.868107 & 0.879450 \\
\hline & 1 & 0.1451 & 1.477 & & & 0.994 & 0.767477 & 0.800675 & 0.805856 \\
\hline & 0.5 & 0.1362 & 1.44 & & & 0.991 & 0.820272 & 0.814300 & 0.819226 \\
\hline \multirow{3}{*}{ Henderson and Pabis } & 2 & 0.01 & & 0.549 & & 0.975 & 0.022440 & 0.069651 & 0.142830 \\
\hline & 1 & 0.03 & & 0.565 & & 0.97 & 0.018136 & -0.022800 & 0.123878 \\
\hline & 0.5 & 0.03 & & 0.665 & & 0.984 & 0.016528 & 0.018005 & 0.116290 \\
\hline
\end{tabular}


Table (3): Statistical analyses of fitted mathematical models to thin layer drying data of red onion at $80 \mathrm{C}^{\circ}$

\begin{tabular}{|c|c|c|c|c|c|c|c|c|c|}
\hline \multirow{2}{*}{ Model } & \multirow{2}{*}{ Thickness } & \multicolumn{4}{|c|}{ Constants } & \multirow{2}{*}{$\mathbf{R}^{2}$} & \multirow{2}{*}{$X^{2}$} & \multirow{2}{*}{ MBE } & \multirow{2}{*}{ RMSE } \\
\hline & & $\mathbf{k}$ & $\mathbf{n}$ & $\mathbf{a}$ & b & & & & \\
\hline \multirow{3}{*}{ Newton } & 2 & 0.022 & & & & 0.916 & 0.065299 & 0.231040 & 0.240922 \\
\hline & 1 & 0.062 & & & & 0.969 & 0.011 & 0.0694186 & 0.0972477 \\
\hline & 0.5 & 0.085 & & & & 0.979 & 0.006 & 0.0502087 & 0.0709296 \\
\hline \multirow{3}{*}{ Page } & 2 & 17.725 & 1.143 & & & 0.997 & 0.067571 & -0.158148 & 0.229250 \\
\hline & 1 & 8.732 & 1.346 & & & 0.995 & 0.029712 & -0.094733 & 0.145681 \\
\hline & 0.5 & 7.478 & 1.271 & & & 0.996 & 0.033023 & -0.096955 & 0.1407607 \\
\hline \multirow{3}{*}{ Modified Page (I) } & 2 & 12.370 & 1.143 & & & 0.997 & 0.067571 & -0.158148 & 0.229250 \\
\hline & 1 & 5.002 & 1.346 & & & 0.995 & 0.029712 & -0.216368 & 0.391781 \\
\hline & 0.5 & 4.869 & 1.271 & & & 0.996 & 0.033023 & -0.096955 & 0.140761 \\
\hline \multirow{3}{*}{ Modified Page (II) } & 2 & 0.044 & 1.143 & & & 0.997 & 0.936657 & 0.837646 & 2.560585 \\
\hline & 1 & 0.087 & 1.346 & & & 0.995 & 1.161649 & 0.904222 & 0.910906 \\
\hline & 0.5 & 0299 & 1.271 & & & 0.996 & 1.374212 & 0.902322 & 0.962146 \\
\hline \multirow{3}{*}{ Henderson and Pabis } & 2 & 0.04 & & 0.873 & & 0.996 & 0.004424 & 0.019577 & 0.058656 \\
\hline & 1 & 0.06 & & 0.647 & & 0.969 & 0.025630 & -0.034421 & 0.135304 \\
\hline & 0.5 & 0.08 & & 0.750 & & 0.979 & 0.022268 & -0.026802 & 0.115590 \\
\hline
\end{tabular}


Table (4): Statistical analyses of fitted mathematical models to thin layer drying data of white onion at $65 \mathrm{C}^{\circ}$

\begin{tabular}{|c|c|c|c|c|c|c|c|c|c|}
\hline \multirow{2}{*}{ Model } & \multirow{2}{*}{ Thickness } & \multicolumn{4}{|c|}{ Constants } & \multirow{2}{*}{$\mathbf{R}^{2}$} & \multirow{2}{*}{$X^{2}$} & \multirow{2}{*}{ MBE } & \multirow{2}{*}{ RMSE } \\
\hline & & $\mathbf{k}$ & $\mathbf{n}$ & $\mathbf{a}$ & b & & & & \\
\hline \multirow{3}{*}{ Newton } & 2 & 0.008 & & & & 0.897 & 0.110882 & 0.3176631 & 0.324965 \\
\hline & 1 & 0.024 & & & & 0.983 & 0.026774 & 0.1205219 & 0.1584310 \\
\hline & 0.5 & 0.029 & & & & 0.947 & 0.031513 & 0.1363524 & 0.1705540 \\
\hline \multirow{3}{*}{ Page } & 2 & 29.874 & 1.436 & & & 0.993 & 0.053621 & -0.147524 & 0.220259 \\
\hline & 1 & 16.007 & 1.596 & & & 0.995 & 0.032613 & -0.104941 & 0.168926 \\
\hline & 0.5 & 12.061 & 1.571 & & & 0.988 & 0.028908 & -0.087024 & 0.1563983 \\
\hline \multirow{3}{*}{ Modified Page (I) } & 2 & 2.1641 & 1.436 & & & 0.993 & 0.053621 & -0.147524 & 0.220259 \\
\hline & 1 & 1.4766 & 1.596 & & & 0.995 & 0.032613 & -0.138905 & 0.242453 \\
\hline & 0.5 & 1.0012 & 1.571 & & & 0.988 & 0.028908 & -0.087024 & 0.156398 \\
\hline \multirow{3}{*}{ Modified Page (II) } & 2 & 0.074 & 1.436 & & & 0.993 & 0.793750 & 0.839714 & 0.847440 \\
\hline & 1 & 0.160 & 1.596 & & & 0.995 & 0.668091 & 0.767923 & 0.764578 \\
\hline & 0.5 & 0.482 & 1.571 & & & 0.988 & 0.061726 & 0.149135 & 0.228538 \\
\hline \multirow{3}{*}{ Henderson and Pabis } & 2 & 0.01 & & 0.661 & & 0.991 & 0.017699 & 0.098969 & 0.126545 \\
\hline & 1 & 0.02 & & 0.535 & & 0.983 & 0.010465 & 0.010866 & 0.095692 \\
\hline & 0.5 & 0.03 & & 0.458 & & 0.947 & 0.017272 & -0.030054 & 0.120893 \\
\hline
\end{tabular}


Table (5): Statistical analyses of fitted mathematical models to thin layer drying data of white onion at $80 \mathrm{C}^{\circ}$

\begin{tabular}{|c|c|c|c|c|c|c|c|c|c|}
\hline \multirow{2}{*}{ Model } & \multirow{2}{*}{ Thickness } & \multicolumn{4}{|c|}{ Constants } & \multirow{2}{*}{$\mathbf{R}^{2}$} & \multirow{2}{*}{$X^{2}$} & \multirow{2}{*}{ MBE } & \multirow{2}{*}{ RMSE } \\
\hline & & $\mathbf{k}$ & $\mathbf{n}$ & $\mathbf{a}$ & b & & & & \\
\hline \multirow{3}{*}{ Newton } & 2 & 0.017 & & & & 0.891 & 0.113869 & 0.318052 & 0.320129 \\
\hline & 1 & 0.071 & & & & 0.991 & 0.008998 & 0.070565 & 0.086592 \\
\hline & 0.5 & 0.088 & & & & 0.988 & 0.008649 & 0.068765 & 0.083181 \\
\hline \multirow{3}{*}{ Page } & 2 & 15.800 & 1.274 & & & 0.997 & 0.052483 & -0.123014 & 0.204905 \\
\hline & 1 & 9.328 & 1.239 & & & 0.999 & 0.042214 & -0.088347 & 0.167759 \\
\hline & 0.5 & 7.675 & 1.221 & & & 0.996 & 0.038437 & -0.071248 & 0.1518625 \\
\hline \multirow{3}{*}{ Modified Page (I) } & 2 & 8.726 & 1.274 & & & 0.997 & 0.052483 & -0.123014 & 0.204905 \\
\hline & 1 & 6.063 & 1.239 & & & 0.999 & 0.042214 & -0.226870 & 0.369671 \\
\hline & 0.5 & 5.307 & 1.221 & & & 0.996 & 0.038437 & -0.071248 & 0.151862 \\
\hline \multirow{3}{*}{ Modified Page (II) } & 2 & 0.039 & 1.274 & & & 0.997 & 0.953385 & 0.872295 & 0.873332 \\
\hline & 1 & 0.093 & 1.239 & & & 0.999 & 1.143561 & 0.885756 & 0.873140 \\
\hline & 0.5 & 0.307 & 1.221 & & & 0.996 & 0.599885 & 0.617791 & 0.599942 \\
\hline \multirow{3}{*}{ Henderson and Pabis } & 2 & 0.04 & & 0.696 & & 0.992 & 0.004637 & -0.014492 & 0.060907 \\
\hline & 1 & 0.07 & & 0.727 & & 0.991 & 0.005881 & -0.016116 & 0.062616 \\
\hline & 0.5 & 0.08 & & 0.729 & & 0.988 & 0.008423 & -0.008659 & 0.071091 \\
\hline
\end{tabular}



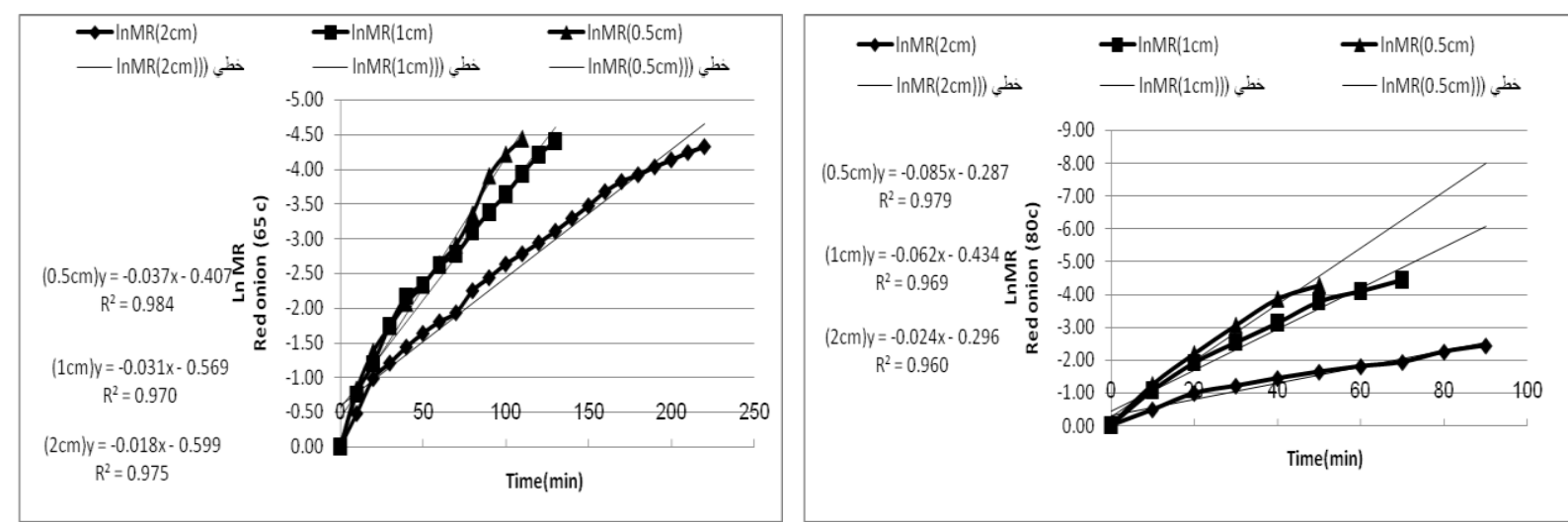

Fig.6 The slope of $\ln (\mathrm{MR})$ versus time in red onion drying temperatures.
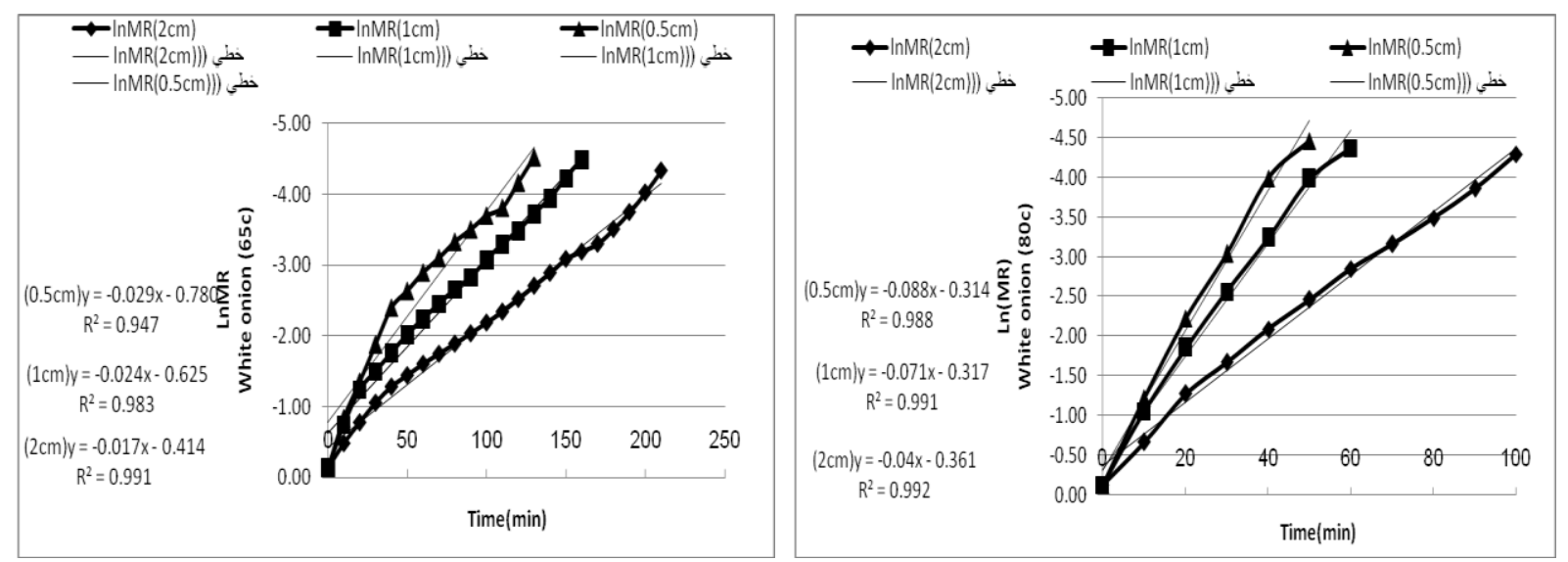

Fig.7 The slope of $\ln (\mathrm{MR})$ versus time in red onion at drying temperatures. 
Table 6: Quality evaluation of dried onion slices according to experimented parameters.

\begin{tabular}{|c|c|c|c|c|c|c|c|c|c|}
\hline variety & $\begin{array}{c}\text { Air } \\
\text { temperature, } \\
{ }^{\circ} \mathrm{C}\end{array}$ & $\begin{array}{c}\text { Slice } \\
\text { thickness, } \\
\text { cm }\end{array}$ & $\mathbf{L}^{*}$ & $a^{*}$ & $\mathbf{b}^{*}$ & $\delta E$ & BI & $\mathbf{R R}$ & COR \\
\hline \multirow{7}{*}{ 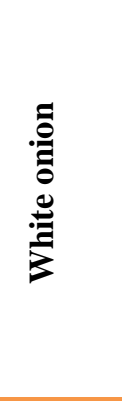 } & & Control & 63.48 & -3.55 & 13.49 & _ & _ & _ & _ \\
\hline & \multirow{3}{*}{65} & 2 & 52.46 & -0.64 & 19.36 & 12.49 & 2.78 & 2.12 & 0.324 \\
\hline & & 1 & 55.01 & 0.13 & 21.06 & 11.94 & 3.98 & 2.48 & 0.374 \\
\hline & & 0.5 & 56.11 & -0.41 & 20.38 & 10.46 & 3.08 & 2.64 & 0.398 \\
\hline & \multirow{3}{*}{80} & 2 & 59.97 & -0.75 & 22.39 & 9.97 & 2.80 & 2.40 & 0.368 \\
\hline & & 1 & 59.38 & 0.12 & 20.12 & 8.62 & 3.51 & 2.43 & 0.370 \\
\hline & & 0.5 & 58.47 & 0.31 & 18.53 & 8.09 & 3.53 & 2.47 & 0.374 \\
\hline \multirow{7}{*}{ 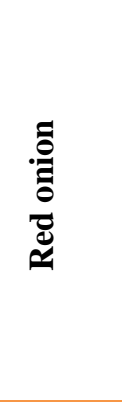 } & & Control & 63.82 & -0.73 & 15.67 & _ & - & - & - \\
\hline & \multirow{3}{*}{65} & 2 & 41.63 & 4.67 & 11.18 & 23.27 & 11.74 & 2.68 & 0.366 \\
\hline & & 1 & 42.04 & 2.64 & 12.61 & 22.25 & 7.48 & 2.51 & 0.341 \\
\hline & & 0.5 & 45.51 & 5.24 & 13.88 & 19.34 & 11.21 & 2.59 & 0.351 \\
\hline & \multirow{3}{*}{80} & 2 & 51.62 & 1.02 & 15.04 & 12.34 & 4.31 & 2.03 & 0.277 \\
\hline & & 1 & 54.06 & 1.74 & 15.74 & 10.07 & 5.20 & 2.67 & 0.361 \\
\hline & & 0.5 & 57.87 & 1.86 & 17.83 & 6.84 & 5.37 & 2.59 & 0.356 \\
\hline
\end{tabular}

\section{CONCLUSIONS}

Based on the above findings, the following are the conclusions:

Temperature of drying air has significant effect on the drying time. It is evident from the examination that the drying onion at $80{ }^{\circ} \mathrm{C}$ was much faster than at $65^{\circ} \mathrm{C}$ with all treatments. For example, in red onion, it took 110, 130, and $220 \mathrm{~min}$ at $65^{\circ} \mathrm{C}$ at $0.5,1$ and $2 \mathrm{~cm}$ slice thicknesses respectively. However, at $80{ }^{\circ} \mathrm{C}$, it took 50,70 , and $90 \mathrm{~min}$, at $0.5,1$ and 2 $\mathrm{cm}$ slice thicknesses respectively. The Page and Modified Page (I) models were the best descriptive models for all treatments; the models were evaluated based on $\mathrm{R}^{2}, \mathrm{X}^{2}$, MBA and RMSE. For product quality assessment, the total color change $(\delta E)$ was greater in the slices dried at higher temperature for red onion only. From the results of color changes and browning index it might be concluded that hot air drying did not cause any defect to onion slices. So it is a good way to dry onions and to maintain quality. The rehydration ratio ranged from 2.03 to 2.68 with 
different parameters. The two varieties of the dried onions were have greater rehydration ratio at lower temperature, $\left(65^{\circ} \mathrm{C}\right)$ compared with the sample dried at higher temperature, $\left(80^{\circ} \mathrm{C}\right)$.

Effective moisture diffusivity of white onion ranged from $1.50 \times 10^{-7}$ to $4.90 \times 10^{-7} \mathrm{~m}^{2} \cdot \mathrm{s}^{-1}$ and for red onion, ranged from $6.25 \times 10^{-7}$ to6.50 $\times 10^{-}$ ${ }^{6} \mathrm{~m}^{2} . \mathrm{s}^{-1}$. The moisture diffusivity increased as drying air temperature was increased for both variety of onion. Same results with different slice thicknesses.

\section{REFERENCES}

AOAC (Association of Official Analytical Chemists) (2000).Official methods of analysis, $17 \mathrm{Ed}$. Washington D.C.

Arslan, D \&Özcen, M.M. (2008). Evaluation of drying methods with respect to drying kinetics, mineral content and color characteristics of rosemary leaves. Energy Convers. Manage. 49: 1258-1264.

Chhninman, M. S. (1984). Evaluation of selected mathematical models for describing thin layer drying of in-shell pecans. Transactions of the ASAE, 27, 610-615.

Crank, J. (1975). The Mathematics of Diffusion, Clarendon Press, Oxford, U.K..

Diamante, L. M., \& Munro, P. A. (1991). Mathematical modeling of hot air drying of sweet potato slices. International Journal of Food Science and Technology, 26, 99.

El Mesery H. S.and Mwithga G.(2012). The drying of onion slices in two types of hot-air convective dryers. African Journal of Agricultural Research Vol. 7(30), pp. 4284-4296, 7 August, 2012 Available online at http://www.academicjournals.org/AJAR DOI: 10.5897/AJAR11.2065.

Khazai, J \&Daneshmandi, S. (2007). Modelling of thin-layer drying kinetics of sesame seed: mathematical and neural networks modelling. International Agrophysics, 21: 335-348.

Liu, Q., \& F. W. Bakker, (1997). Stochastic modeling of grain drying, Part 2: Model development. Journal of Agricultural Engineering Research, 66, 275-280.

Madamb, P.S. (2003). Thin layer drying models for osmotically pre-dried young coconut. Dry. Technol. 21,1759-1780. 
Maskan, M. 2001. Drying, shrinking and rehydration characteristic of kiwi fruit during hot air and microwave drying. J. Food Eng. 48, 177-182.

Mohammadi, A., Rafiee, S., Emam-Djomeh, Z., A. Keyhani, (2008):

Kinetic models for color changes in kiwifruit slices during hot air drying. World Journal of Agricultural Sciences 4(3): 376-383.

Olulusi A.(2014). Hot Air Drying and Quality of Red and White Varieties of Onion. Journal of Agricultural Chemistry and Environment, 3, 13-19. http://www.scirp.org/journal/jacen http://dx.doi.org/10.4236/jacen.2014.34B003.

Zheng, Q., \& J. B. Letchfield, (1991). An optimization of intermittent corn drying in a laboratory scale thin layer dryer. Drying Technology, 9, 383-395.

\section{الملخص العربي}

دراسة تأثير التجفيف بتقنية الحمل الحرارى على جودة نوعين من البصل

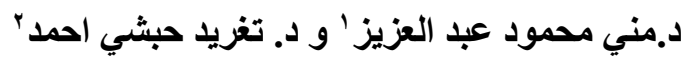

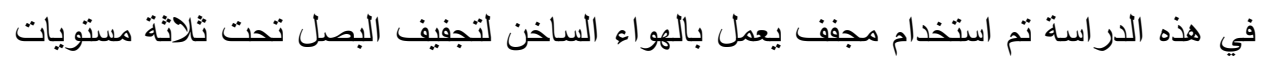

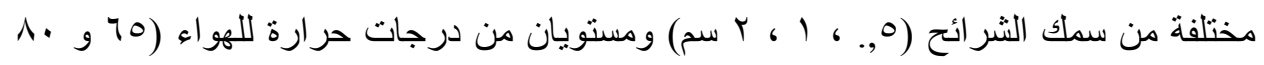
درجة مئوية) لتقدير خصائص التجفيف وتقييم لجودة الثر ائح المجففة. في نهاية التجارب وبعد تحليل البيانات تم التوصل إلى الأتي:

يتم إيقاف التجارب بعد وصول نسبة الرطوبة في العينات إلي ^ \pm (٪ علي أساس رطب.

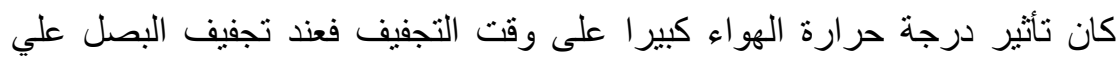

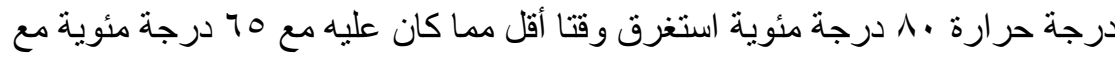

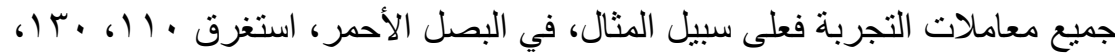

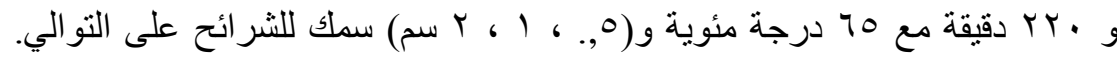

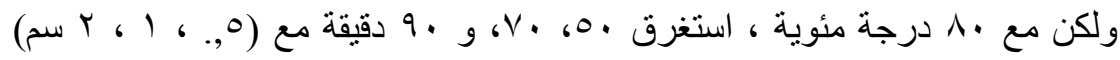

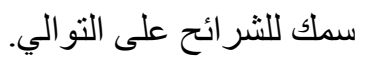

كانت معادلتي Modified Page (I) من أفضل المعادلات نو افقا مع جميع المعاملات.وتم تقييم المعادلات عن طريق Ra Re

' أستاذ الهندسة الزراعية المساعد ـ كلية الزراعة - جامعة الزقازيق. r مدرس الهندسة الزراعية ـ كلية الزراعة ـ ـ جامعة الزقازيق. 


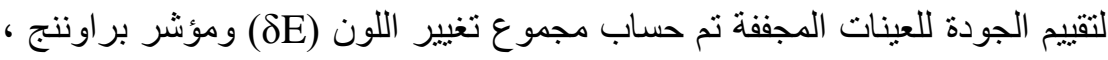

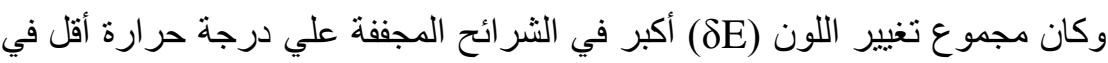

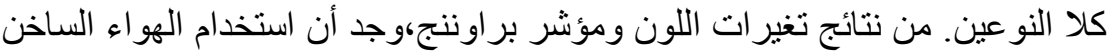

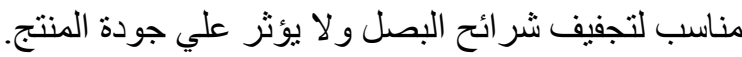

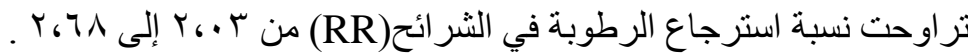

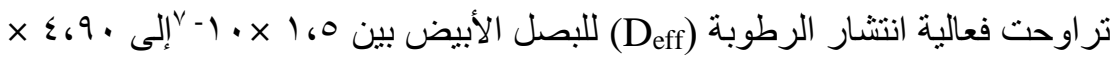

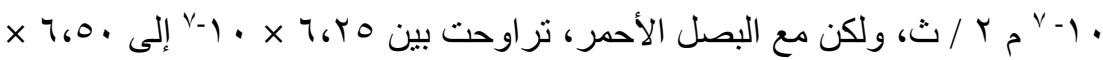

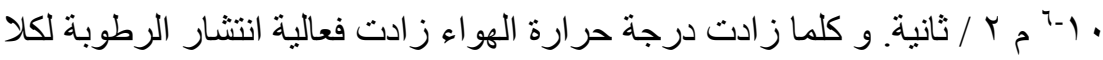

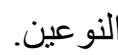

